\title{
Evaluation of Partner Violence in Female Patients with Fibromyalgia Syndrome
}

\author{
Kadın Fibromyalji Hastalarında Eş Şiddetinin Değerlendirilmesi

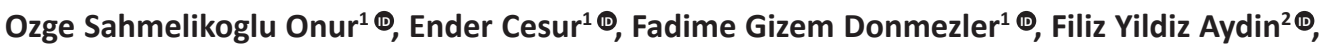 \\ Meltem Vural ${ }^{2} \oplus$, Meltem Guru ${ }^{3} \oplus$
}

${ }^{1}$ Bakirkoy Research and Training Hospital for Psychiatry Neurology and Neurosurgery, Department of Psychiatry, Istanbul, Turkey ${ }^{2}$ Bakirkoy Dr. Sadi Konuk Research and Training Hospital, Department of Physical Medicine and Rehabilitation, Istanbul, Turkey ${ }^{3}$ Gazi University Health Care Center, Department of Psychiatry, Ankara, Turkey

Received: 13 July 2019 / Accepted: 15 December 2019 / Publication date: 26 June 2020

Cite as: Sahmelikoglu Onur Ö, Cesur E, Dönmezler FG, Yıldız Aydın F, Vural M, Guru M. Evaluation of partner violence in female patients with fibromyalgia syndrome. Med J Bakirkoy 2020;16(2):190-6.

ABSTRACT

Objective: Fibromyalgia syndrome (FMS) is a disorder that causes chronic extensive musculoskeletal pain. Although there has been great debate in recent investigations regarding the risk factors of FMS, no agreement has been reached about the pathophysiology of the syndrome. In recent studies, it has been suggested that there is an abnormal response to stress factors in this syndrome due to the neuro-endocrine system perturbation as a result of stress experiences such as abuse during childhood, adolescence or adulthood. In this context, this study aims to evaluate the differences of all types of partner violence experienced by patients with FMS and healthy controls.

Method: Forty-three consecutive married women aged between 18-65 years who were recently diagnosed as having FMS were recruited from Bakirkoy Dr. Sadi Konuk Research Hospital Outpatient Clinic. The diagnosis of FMS was made by experienced physical medicine and rehabilitation physicians according to the American College of Rheumatology (ACR) FMS diagnostic criteria. Patients who were referred to the Bakırköy Psychiatric Research and Training Hospital were evaluated by an experienced psychiatrist. 43 female patients with FMS and 45 female (non-FMS) controls were evaluated with a questionnaire about previous physical, sexual, emotional, social and economic partner violence, the Hamilton Depression and Anxiety Inventories (HAM-D and HAM-A, respectively), and a Visual Analogue Scale (VAS).

Results: The FMS group and healthy control group showed no statistically significant difference in terms of age and the presence of psychiatric administration $(p>0.05)$; however, the sample showed a significant difference with regards to education, occupation status, and history of suicide attempts. Significantly higher scores were observed for partner physical violence (27.9\% vs. $11.1 \%)$, economic violence (48.8\% vs. $13.3 \%)$, social violence (83.7\% vs. $22.3 \%)$, and emotional violence (62.8\% vs. $28.9 \%$ ) in FMS patients than in controls ( $p<0.05)$. Higher HAM-A and HAM-D inventory and VAS scores were observed in the FMS group than controls $(p<0.05)$. A statistically significant positive correlation was observed between VAS and HAM-A, HAM-D scores ( $p<0.05)$.

Conclusion: Our results may have implications to show the effect of partner violence on the clinic and course of FMS.

Keywords: anxiety, depression, fibromyalgia, pain severity, partner violence

öz

Amaç: Fibromiyalji sendromu (FMS), kas iskelet sisteminde yaygın ağrıya neden olan kronik bir hastalıktır. FMS'nin risk faktörleri ile ilgili büyük araştırmalar yapılmasına rağmen, sendromun patofizyolojisi konusunda bir uzlaşmaya varılmamıștır. Yapılan son çalışmalarda, çocukluk, ergenlik veya erişkinlik döneminde suistimal, istismar gibi stres deneyimlerinin bir sonucu olarak nöro-endokrin sistemde bir bozulma olduğu ve bu sebeple stres faktörlerine anormal bir yanıt olduğu öne sürülmüştür. Bu çalışmada FMS olan kadınlarla sağlıkı kontroller arasında eş şiddetinin tüm tipleri açısından farklılıkların araştırılması amaçlanmıştır. Yöntem: Bakırköy Dr. Sadi Konuk Eğitim Araştırma Hastanesi Polikliniği'nde FMS tanısı konan 18-65 yaşları arasındaki kırk üç evli kadın çalışmaya alındı. FMS tanısı Amerikan Romatoloji Derneği (ACR) FMS tanı kriterlerine göre fizik tedavi ve rehabilitasyon uzman doktorları tarafından konuldu. Bakırköy Prof. Dr. Mazhar Osman Ruh ve Sinir Hastalıkları Eğitim ve Araştırma Hastanesi psikiyatri polikliniğine yönlendirilen hastalar deneyimli bir psikiyatrist tarafından değerlendirildi. FMS tanısı konan 43 kadın hasta grubuna ve 45 kadın (FMS tanısı olmayan) sağlıklı kontrol grubuna, sosyodemografik veri formu, önceki cinsel, fiziksel, duygusal, sosyal ve ekonomik eş şiddetini ölçen bir şiddet değerlendirme formu, Hamilton Depresyon ve Anksiyete ölçekleri (HAM-D ve HAM-A) uygulandı. Ağrı şiddetini değerlendirmek için Vizüel Analog Skala (VAS) kullanıldı.

Bulgular: FMS grubu ve sağlıklı kontrol grubu, yaş ortalaması ve daha önce psikiyatri başvurusu varlığı açısından istatistiksel olarak farklıık göstermedi (p>0.05). Bununla birlikte iki grup arasında eğitim durumu, meslek ve intihar girișimlerinin geçmişi açısından önemli farklııklar tespit edildi. Essinden fiziksel şiddet görme $(\% 27,9-\% 11,1)$, ekonomik şiddet (\%48,8-\%13,3), sosyal şiddet (\%83,7-\%22,3) ve duygusal şiddete maruz kalma (\%62,8-\%28,9) FMS'li hasta grubunda kontrol grubundan daha fazla idi ( $p<0.05)$. FMS grubunda HAM-D, HAM-A ve VAS skorları kontrol grubundan daha yüksekti (p<0.05). VAS ve HAM-A, HAM-D skorları arasında istatistiki açıdan anlamlı korelasyon gözlendi ( $p<0.05)$.

Sonuç: Bu sonuçlar, eş şiddetinin FMS'nin ortaya çıkışı ve sürekliliği üzerinde bir etkisi olabileceği ihtimalini artırmaktadır. Ayrıca, bu çalışmadan elde edilen sonuçların sadece tıbbi bakım almak isteyen FMS'li hastalara ait olduğu ve FMS'li tüm hastalara genellenemeyeceği göz önünde bulundurulmalıdır. Kadına yönelik şiddet ve FMS arasındaki ilişki konusunda daha fazla araştırma yapılmalıdır.

Anahtar kelimeler: anksiyete, depresyon, fibromyalji, ağrı şiddeti, eş şiddeti

Corresponding Author:

meltemguru@gmail.com
Ö. Sahmelikoglu Onur 0000-0003-0447-4636

E. Cesur 0000-0002-8982-8626

F.G. Donmezler 0000-0002-0902-6982
F. Yildiz Aydin 0000-0003-4763-7538

M. Vural 0000-0003-4360-8318

M. Guru 0000-0001-8751-6453

(c) Telif hakkı Sağlık Bilimleri Üniversitesi Bakırköy Dr. Sadi Konuk Eğitim ve Araştırma Hastanesi'ne aittir. Logos Tıp Yayıncılık tarafindan yayınlanmaktadır. Bu dergide yayınlanan bütün makaleler Creative Commons Atff-GayriTicari 4.0 Uluslararası Lisansı ile lisanslanmıştır.

(c) Copyright Health Sciences University Bakırköy Sadi Konuk Training and Research Hospital. This journal published by Logos Medical Publishing.

Licenced by Creative Commons Attribution-NonCommercial 4.0 International (CC BY-NC 4.0) 


\section{INTRODUCTION}

Fibromyalgia syndrome (FMS) is a disorder that causes chronic extensive musculoskeletal pain and multiple tender points that are painful to palpation (1). FMS, with a $0.7-3.2 \%$ worldwide prevalence, is less prevalent in men than women ${ }^{(2)}$. Although there has been great debate in recent investigations regarding the risk factors of FMS, the theories about the pathophysiology of the FMS have been contraversial ${ }^{(3-6)}$. In recent studies, a vulnerability to stress factors has been suggested in this syndrome due to the neuroendocrine system perturbation as a result of stress experiences such as abuse during childhood, adolescence or adulthood ${ }^{(7)}$. In a study FMS patients, with a history of past sexual abuse had worser experience of the illness than patients without abuse. However, in that study FMS was not significantly more likely among adult survivors of sexual violence than that of non-abused counterparts ${ }^{\left({ }^{8}\right)}$. Moreover, a combination of reported physical and sexual abuse is significantly more likely during child or adulthood among patients with FMS than in those without FMS ${ }^{(9)}$.

Violence against women varies in the literature according to the cultural factors, the description used, the age range of population studied, and the duration of the observation period ${ }^{(10-14)}$. Depression, anxiety, and posttraumatic stress disorder are proposed to be more common in women having violence exposure than in women with no history of violence ${ }^{(15,16)}$.

Although previous studies have focused on the health implications of physical and sexual violence exposure, there is a limited number of studies about psychological, economic, and social violence. The main difference observed is the type of violence that is more closely related to the syndrome and age of violence exposure. Some studies have claimed a greater association between physical abuse in adulthood. Moreover, a combination of reported physical and sexual abuse is significantly more likely during childhood or adulthood among patients with FMS than in those without FMS (17), while others find emotional abuse ${ }^{(18,19)}$ or sexual abuse during childhood ${ }^{(20)}$. Also in a study it was suggested that the experience of child abuse might be related with FMS symptom severity and may result polysymptomatic distress and pain (21).
The first aim of our study was to evaluate the differences of partner violence including economic violence and social violence experienced by patients with FMS and healthy controls. The second aim of our study was to investigate the effect of violence severity on the severity of depression and anxiety.

\section{MATERIALS AND METHODS}

The study sample consisted of 43 FMS patients who were reffered from Bakirkoy Dr. Sadi Konuk Research Hospital Physical Medicine and Rehabilitation Outpatient Clinic to the outpatient treatment unit of Bakirkoy Research \& Training Hospital for Psychiatry, Neurology and Neurosurgery between January 2016 and August 2017. Forty-three consecutive married women aged between 18-65 years who were recently diagnosed as having FMS were recruited from Bakirkoy Dr. Sadi Konuk Research Hospital Physical Medicine and Rehabilitation Outpatient Clinic. The diagnosis of FMS was made by experienced physical medicine and rehabilitation physicians according to the American College of Rheumatology (ACR) FMS diagnostic criteria ${ }^{(1)}$. Patients who were referred to the Bakırköy Psychiatric Research and Training Hospital were evaluated by an experienced psychiatrist. Subjects without a sufficient mental capacity for verbal communication and patients with neurologic or physical illnesses those with a history of psychosurgery or other brain surgery, alcohol/drug addiction, head trauma, comorbid psychiatric disease other than specific phobia, presenting psychotic symptoms, having electroconvulsive therapy in the last 6 months, were excluded. Women accompanied by their husbands were excluded from the study. The same researchers invited the relatives of hospital workers to participate in the research. Physical medicine and rehabilitation physician and psychiatrist interviewed with the ones who accepted. Fortyfive married women aged between 18-65 years were included in the study after being confirmed to not have FMS as control group. Written informed consent was obtained from both the patients with FMS and controls prior to participation. The Ethics Committee of Bakırköy Education and Research Hospital approved the study (Protocol No: 495, Date:3rd November 2015). A Socio-demographic Data Form, the Hamilton Anxiety Rating Scale (HAM-A), Hamilton Depression Rating Scale (HAM-D), and the Partner Violence Data 
Form were administered to both the control and FMS groups. In an attempt to measure the severity of pain symptoms, a visual analogue scale (VAS) was referred to the FMS group.

\section{Sociodemographic Data Form}

This form was composed of questions about demographic variables such as occupation, age, education level, sex, and other characteristics. Both control and patient groups were evaluated with this data form.

\section{Hamilton Depression Rating Scale (HAM-D)}

The HAM-D test measures is administered by a physician to individuals to evaluate the severity of depression symptoms. It was developed by Hamilton (22). The validity and reliability of the Turkish version was performed by Akdemir et al. ${ }^{(23)}$.

\section{Hamilton Anxiety Rating Scale (HAM-A)}

The HAM-A was used to measure anxiety levels and symptom distribution ${ }^{(24)}$. In 1998 , the validity and reliability of the Turkish version of the scale was confirmed ${ }^{(25)}$.

\section{Visual Analogue Scale (VAS)}

The VAS is a continuous line from which the patient chooses the point that indicates their pain intensity. Patients give a score to the intensity of pain (for pain intensity, 10 represents the worst possible pain and 0 represents absence of pain) ${ }^{(26)}$.

\section{Partner Violence Data Form}

The presence of partner violence and type was evaluated with this semi-structured form prepared by the authors. The Conflict Tactics Scale ${ }^{(27)}$ and a scale which is used to evaluate domestic violence in Turkey in a prior study were used to define the violence type ${ }^{(28)}$. The questionnaire including questions about five types of violence (social, physical, emotional, economic and sexual) was referred to participants by a semi-structured interview. The physical violence questions were adapted: "Have you ever been slapped, kicked, hit, or hurt otherwise physically by your husband?" (yes/no). The sexual violence questions were as follows: "Have you ever been forced into sexual activities by your husband?" (yes/no).

The database was analyzed using the SPSS Statistics, version 18.0 software package (SPSS, Chicago, IL). In addition to descriptive statistical methods like frequency, mean, standard deviation, the independent sample t-test and Chi-square test were used in comparison of two groups. Spearman's correlation analysis was used to investigate the relationship between the two variables. A value of $p<0.05$ was considered to be statistically significant.

\section{RESULTS}

We assessed 70 FMS. Participants accompanied by their husbands ( $n=14)$, with insufficient mental capacity for verbal communication $(n=5)$, presenting psychotic symptoms $(n=2)$, drug/alcohol use $(n=2)$, Bipolar Disorder $(n=2)$, neurologic disease $(n=12)$ were excluded as seen in the Figure 1. This resulted in a sample of 43 patients with FMS available for the study (Figure 1).

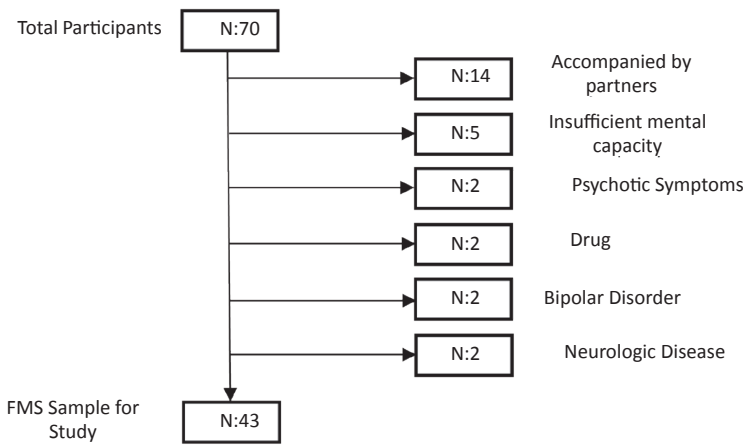

Figure 1. Assesment of patient group for inclusion.

Description of the study population.70 patients with FMS were interviewed. 14 were accompanied with their husbands. 5 were with insufficient mental capacity for verbal communication, 2 had psychotic symptoms (1 had auditory hallucinations and other had persecution delusions), 2 were drug use (alcohol abuse), 2 had a diagnoses of Bipolar Disorder Type 1, 2 had Epilepsy. These patients were excluded from the study. As a result, 43 patients with FMS were available for the study.

The FMS group and healthy control group showed no statistically significant difference in terms of age and the presence of psychiatric administration ( $p>0.05)$; however, the sample showed a significant difference with regards to education, occupation status, and history of suicide attempts $(p<0.05)$. As shown on Table 1, the results revealed that education level and occupation status were less among the FMS group compared with the controls.

When the groups were compared by the means of violence subscales, patients with FMS showed grea- 
Table 1. Clinical and sociodemographic variables of the groups.

\begin{tabular}{|c|c|c|c|c|c|}
\hline & & 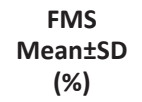 & $\begin{array}{c}\text { Control } \\
\text { Mean士SD } \\
(\%)\end{array}$ & $t / x^{2}$ & p \\
\hline Age & & $44.77 \pm 7.69$ & $44.30 \pm 10.92$ & 0.237 & $0.813^{1}$ \\
\hline \multirow[t]{5}{*}{ Education } & None & $1(2.3 \%)$ & $0(0 \%)$ & 15.61 & $0.000^{2}$ \\
\hline & Elementary & 25 (58.1\%) & $18(40.0 \%)$ & & \\
\hline & Middle & $7(16.3 \%)$ & $5(11.1 \%)$ & & \\
\hline & High & 7 (16.3\%) & 5 (11.1\%) & & \\
\hline & University & $3(7 \%)$ & $17(37.8 \%)$ & & \\
\hline \multirow[t]{6}{*}{ Occupation } & Housewife & 35 (81.4\%) & 11 (24.4\%) & 37.24 & $0.008^{2}$ \\
\hline & $\begin{array}{l}\text { Seasonal } \\
\text { employee }\end{array}$ & $0(0 \%)$ & $1(2.2 \%)$ & & \\
\hline & $\begin{array}{l}\text { Regular } \\
\text { employee }\end{array}$ & $1(2.3 \%)$ & $8(17.8 \%)$ & & \\
\hline & Civil Servant & $3(7 \%)$ & 21 (46.7\%) & & \\
\hline & Employer & $1(2.3 \%)$ & 4 (8.9\%) & & \\
\hline & Student & $3(7 \%)$ & $0(0 \%)$ & & \\
\hline Psychiatric & Present & $4(9.3 \%)$ & $3(6.7 \%)$ & 0.209 & $0.710^{2}$ \\
\hline Administration & Absent & 39 (90.7\%) & 42 (93.3\%) & & \\
\hline Suicide & Present & 4 (9.3\%) & $0(0 \%)$ & 4.385 & $0.050^{2}$ \\
\hline Attempt & Absent & 39 (90.7\%) & 45 (100\%) & & \\
\hline
\end{tabular}

FMS: Fibromyalgia Syndrome; SD: standard deviation

${ }^{1}$ Independent sample t-test

${ }^{2}$ Chi-square test

${ }^{*} p<0.05$

Table 3. Comparison of anxiety and depression scores between the groups.

\begin{tabular}{|c|c|c|c|c|c|}
\hline & & $\begin{array}{c}\text { FMS } \\
\text { Mean } \pm S D\end{array}$ & $\begin{array}{c}\text { Control } \\
\text { Mean士SD }\end{array}$ & $\mathbf{t}$ & $p$ \\
\hline \multirow{5}{*}{$\begin{array}{l}\text { Hamilton } \\
\text { Depression } \\
\text { Hamilton } \\
\text { Anxiety }\end{array}$} & & $21.8 \pm 11.1$ & $3.8 \pm 4.82$ & -9.89 & 0.000 \\
\hline & Psychic & $11.8 \pm 5.9$ & $2.82 \pm 3.64$ & -9.57 & 0.000 \\
\hline & Anxiety & & & & \\
\hline & $\begin{array}{l}\text { Somatic } \\
\text { Anxiety }\end{array}$ & $20.13 \pm 8.48$ & $2.66 \pm 4.68$ & -12.03 & 0.000 \\
\hline & Total & $32.0 \pm 12.50$ & $5.48 \pm 8.10$ & -11.85 & 0.000 \\
\hline
\end{tabular}

FMS: Fibromyalgia syndrome

Independent t-test

${ }^{*} p<0.05$

ter presence of economic, physical, social, and emotional violence than controls $(p<0.05)$. A comparison of the presence of sexual violence yielded no statistical difference ( $p>0.05)$ (Table 2).

A comparison of the groups by the means of the HAM-A and HAM-D subscales, patients with FMS had higher scores than the controls in all subscales $(p<0.05)$ (Table 3).

In the FMS group a positive significant correlation was found between VAS score and HAM-A and HAM-D scores $(p<0.05)$ (Table 4$)$.
Table 2. Comparison of groups in terms of types of violence.

\begin{tabular}{llcccc}
\hline & & $\begin{array}{c}\text { FMS } \\
\mathbf{n}(\%)\end{array}$ & $\begin{array}{c}\text { Control } \\
\mathbf{n}(\%)\end{array}$ & $\mathbf{x}^{\mathbf{2}}$ & $\mathbf{p}$ \\
\hline Physical & Present & $12(27.9 \%)$ & $5(11.1 \%)$ & 3.980 & $0.040^{*}$ \\
Violence & Absent & $31(72.1 \%)$ & $40(88.9 \%)$ & & \\
Sexual & Present & $4(9.3 \%)$ & $1(2.2 \%)$ & 2.057 & 0.150 \\
Violence & Absent & $39(90.7 \%)$ & $44(97.8 \%)$ & & \\
Emotional & Present & $27(62.8 \%)$ & $13(28.9 \%)$ & 10.193 & $0.010^{*}$ \\
Violence & Absent & $16(37.2 \%)$ & $32(71.1 \%)$ & & \\
Economic & Present & $21(48.8 \%)$ & $6(13.3 \%)$ & 13.032 & $0.010^{*}$ \\
Violence & Absent & $22(51.2 \%)$ & $39(86.7 \%)$ & & \\
Social & Present & $36(83.7 \%)$ & $10(22.2 \%)$ & 33.334 & $0.010^{*}$ \\
Violence & Absent & $7(10.3 \%)$ & $35(77.8 \%)$ & & \\
\hline
\end{tabular}

FMS: Fibromyalgia syndrome

Chi-square test

$* p<0.05$

Table 4. Correlation of VAS score with hamilton anxiety and hamilton depression scores.

\begin{tabular}{|c|c|c|c|c|c|c|c|}
\hline \multicolumn{2}{|c|}{$\begin{array}{c}\text { Hamilton } \\
\text { Anxiety } \\
\text { Psychic }\end{array}$} & \multicolumn{2}{|c|}{$\begin{array}{l}\text { Hamilton } \\
\text { Anxiety } \\
\text { Somatic }\end{array}$} & \multicolumn{2}{|c|}{$\begin{array}{c}\text { Hamilton } \\
\text { Anxiety } \\
\text { Total }\end{array}$} & \multicolumn{2}{|c|}{$\begin{array}{l}\text { Hamilton } \\
\text { Depression }\end{array}$} \\
\hline$r$ & $\mathbf{p}$ & $r$ & $p$ & $r$ & $\mathbf{p}$ & $r$ & $\mathbf{p}$ \\
\hline
\end{tabular}

VAS $0.3690 .015^{*} 0.4670 .002 * 0.4660 .002 * 0.4650 .002 *$

VAS: Visual Analogue Scale

Spearman Correlation

$* p<0.05$

\section{DISCUSSION}

We found that patients with FMS were exposed to more partner violence than control subjects. In addition, subjects with FMS demonstrated increased levels of pain severity, anxiety, and depression compared with the control group. In the FMS group, the level of pain severity was positively correlated with anxiety and depression levels. What distinguishes our study from the others is the investigation of all types of violence.

Much research has been conducted on the relationship between violence against women and somatic symptoms. In a study, it was suggested that exposure to violence had a negative effect on physical health independent from the effect on mental health due to increased vulnerability to disease and illness as a result of it being a 'stressful event' (29). Eberhard-Gran et al. (30) found high correlations between levels of sexual and physical violence and the amount of somatic symptoms and diseases including FMS. In our study, we also found a statistically positive correlation between pain severity and anxiety and depression levels. 
The focus in recent research has been on the relationship between life-time exposure to physical and sexual violence and FMS. Since children's brain are more vulnerable than adults' brains, it may be suggested that there can be differences according to the time of violence exposure ${ }^{(31)}$. More damage may be expected if exposure to violence occurs during childhood because children's brains are still developing. However, due to higher resilience of children's brains, another possibility is that damage is minimized in a way to 're-wire' themselves ${ }^{(32)}$. Some studies reported that physical abuse in adulthood gave rise to the greatest symptoms in patients with FMS ${ }^{(18)}$, whereas others claimed a greater association between emotional ${ }^{(17)}$ or sexual abuse during childhood ${ }^{(18,20,33-35)}$. Hauser et al. ${ }^{(36)}$ found a higher frequency of retrospectively reported childhood adversities and of lifetime traumatic events in FMS patients than control group. Also in another study it was suggested that the onset of FMS was perceived as an ineluctable result of mental or physical trauma ${ }^{(37)}$. In our study, only partner violence during adulthood was investigated and the physical, emotional, economic, and social violence were found to be higher in the patients with FMS cases than in the control group. Violence during adulthood may also be greater in patients with FMS, as with childhood violence.

Taylor et al. ${ }^{(8)}$ noted a higher prevalence of sexual violence experienced by FMS patients. Another study found that, in cases of sexual violence, the severity and number of symptoms were found higher in healthcare institutions in addition to the use of pain medication ${ }^{(8,17)}$. Boisset-Pioro et al. ${ }^{\left({ }^{(9)}\right.}$ found more life-time physical and sexual violence among women with FMS than in their control group, but there was no statistically significant difference in the type of sexual violence. Similarly, there was no statistically significant difference in sexual partner violence between the FMS and control groups in our study. The fact that different outcomes have been achieved in terms of sexual violence may be due to differences in the questions asked. The questions we used to identify violence were those used in a recent study of violence against women in our country ${ }^{(28)}$. This may have led to a change in the questions asked in the studies according to cultures.
Although several studies have investigated physical and sexual violence in FMS, little attention has been paid to social and emotional violence. Aaron et al. ${ }^{(38)}$ also underlined the emotional abuse experienced by FMS patients. The high prevalence of emotional abuse among the patients with FMS in our study also contributes a new aspect because previous studies have not investigated emotional violence as much as physical and sexual violence.

As far as we know, there are limited number of studies in which all types of violence were investigated in women with FMS in our country. Another significant strength of our study was that the sample comprised patients with FMS who had not been treated before. However, there are some limitations of our study. First, since participants accompanied by their husbands were excluded remove a possible form of man's control over woman, the frequency of violence in these women might be higher. Furthermore, self-reporting bias of a socially unacceptable, intimate subject of this study should also be kept in mind. Finally, it should also be considered that subjects in this study were help-seeking members of the FMS population and and the results may not be generalizable to the whole group.

\section{CONCLUSIONS}

Although our study is cross-sectional and does not suggest a causal relationship, our findings suggest that domestic violence in marriage may play a role in pain severity and accompanying symptoms of depression and anxiety in FMS. It is also noteworthy that depression and anxiety levels are associated with pain severity. Therefore, it may be beneficial to investigate domestic violence during the treatment and follow-up period of patients with FMS, to evaluate the symptoms of anxiety and depression, to take precautions for such patients, and to develop appropriate treatment approaches. The physical and mental results of violence in different types may be carried by the individual. Understanding any exposure to violence may give information about individual's health behavior and any possible reluctance to undergo treatment in patients with FMS. 
Acknowledgement: This paper was given as an oral presentation at the Congress of Clinical Child and Adult Psychiatry held in Istanbul on 23-25 September 2016.

Ethics Committee Approval: T. C. Ministry of Health, Public Hospitals Authority Turkey in Istanbul Bakirkoy Region Association of Public Hospitals Secretary General Prof. Bakirkoy Dr. Mazhar Osman Mental Health and Neurological Diseases Training and Research Hospital Ethics Committee approval was received (03.11.2015/495).

Conflict of Interest: The authors declare no conflict of interest.

Funding: This research did not receive any specific grant from funding agencies in the public,commercial or not-for-profit sectors.

Informed Consent: Was optained.

\section{REFERENCES}

1. Wolfe F, Smythe HA, Yunnus MB, Bennett RM, Bombardier C, Goldenberg DL, et al. The American College of Rheumatology 1990 criteria for the classification of fibromyalgia. Arthritis \& Rheumatism. 1990;33:160-72.

https://doi.org/10.1002/art.1780330203

2. Lorentzen F. Fibromyalgia: a clinical challenge. Journal of intern medicine. 1994;235:199-203. https://doi.org/10.1111/j.1365-2796.1994.tb01060.x

3. Leza JC. Fibromyalgia: a challenge for neuroscience. Revista de Neurologia. 2003;36:1165-75.

https://doi.org/10.33588/rn.3612.2003154

4. Panerai $A E$, Vecchiet J, Panzeri $P$, Meroni $P$, Scarone $S$, Pizzigallo $E$, et al. Peripheral blood mononuclear cell Betaendorphin concentration is decreased in chronic fatigue syndrome and fibromyalgia but not in depression: preliminary report. The Clinical Journal of Pain. 2002;18:270-3. https://doi.org/10.1097/00002508-200207000-00008

5. Klerman EB, Goldenberg DL, Brown EN, Maliszewski AM, Adler GK. Circandian Rhythms of women with fibromyalgia. The Journal of Clinic Endocrinology \& Metabolism. 2001;86:1034-9. https://doi.org/10.1210/jc.86.3.1034

6. Gur A, Cevik R, Nas K, Colpan L, Sarac S. Cortisol and hypothalamic-pituitary-gonadal axis hormones in follicularphase women with fibromyalgia and chronic fatigue syndrome and effect of depressive symptoms on these hormones. Arthritis Research \& Therapy. 2004;6:232-8.

https://doi.org/10.1186/ar1163

7. Neeck G, Crofford LJ. Neuroendocrine perturbations in fibromalgia and chronic fatigue syndrome. Rheumatic Disease Clinics of North America. 2000;26:989-1002.

https://doi.org/10.1016/S0889-857X(05)70180-0

8. Taylor ML, Trotter DR, Csuka ME. The prevalence of sexual abuse in women with fibromyalgia. Arthritis \& Rheumatism. 1995;38,229-34

https://doi.org/10.1002/art.1780380211

9. Boisset-Pioro MH, Esdaile JM, Fitzcharles MA. Sexual and physical abuse in women with fibromyalgia syndrome. Arthritis \& Rheumatism. 1995;38:235-41. https://doi.org/10.1002/art.1780380212

10. McCauley J, Kern DE, Kolodner K, Dill L, Schroeder AF,
DeChant HK et al. The "battering syndrome": prevalence and clinical charecteristics of domestic violence in primary care internal medicine practices.. Annals of Internal Medicine. 1995;123(10):737-46. https://doi.org/10.7326/0003-4819-123-10-199511150-00001

11. Campbell J, Jones AS, Dienemann J, Kub J, Schollenberger J, $\mathrm{O}^{\prime}$ Campo $\mathrm{P}$ et al. Intimate partner violence and physical health consequences. Archives of Internal Medicine. 2002;162:1157-63.

https://doi.org/10.1001/archinte.162.10.1157

12. Nicolaidis C, Curry MA, McFarland B, Gerrity M. Violence, mental health, and physical symptoms in an academic internal medicine practice. Journal of General Internal Medicine. 2004;19:819-27. https://doi.org/10.1111/j.1525-1497.2004.30382.x

13. Campbell JC. Health consequences of intimate partner violence. Lancet. 2002;359:1331-6. https://doi.org/10.1016/S0140-6736(02)08336-8

14. Krug EG, Mercy JA, Dahlberg LL, Zwi AB. The world report on violence and health. The Lancet. 2002, Volume 360, Issue 9339, Pages 1083-8. https://doi.org/10.1016/S0140-6736(02)11133-0

15. Golding JM. Intimate partner violence as a risk factor for mental disorders: a meta-analysis. Journal of Family Violence. 1999;14:99-132. https://doi.org/10.1023/A:1022079418229

16. Coker AL, Weston R, Creson DL, Justice B, Blakeney P. PTSD symptoms among men and women survivors of intimate partner violence: the role of risk and protective factors. Violence Victims. 2005;20:625-43. https://doi.org/10.1891/0886-6708.20.6.625

17. Alexander RW, Aaron LA, Alberts KR, Martin MY,Stewart KE, Bradley LA, et al. Sexual and physical abuse in women with fibromyalgia: association with outpatient health care utilization and pain medication usage. Arthritis \& Rheumatology 2005;11:102-15. https://doi.org/10.1002/art.1790110206

18. Van Houdenhove B, Neerinckx E, Lysens R, Vertommen $H$, Van Houdenhove L, Onghena $P$, et al. Victimization in chronic fatigue syndrome and fibromyalgia in tertiary care: a controlled study on prevalence and characteristics. Psychosomatics. 2001;42:21-8. https://doi.org/10.1176/appi.psy.42.1.21

19. Varinen A, Kosunen E, Mattila K, Koskela T, Sumanen M. The relationship between childhood adversities and fibromyalgia in the general population. Journal of Psychosomatic Research. 2017;99:137-42. https://doi.org/10.1016/j.jpsychores.2017.06.011

20. Weisbecker I, Floyd A, Dedert E, Salmon P, Sephton S. Childhood trauma and diurnal cortisol disruption in fibromyalgia syndrome. Psychoneuroendocrinology. 2006;31:31224. https://doi.org/10.1016/j.psyneuen.2005.08.009

21. Ortiz R, Ballard ED, Machado-Vieira R, Saligan LN, Walitt B. Quantifying the influence of child abuse history on the cardinal symptoms of fibromyalgia. Clin Exp Rheumatol. 2016;34(2 Suppl 96):S59-66.

22. Hamilton M. A rating scale for depression. Journal of Neurology, Neurosurgery, and Psychiatry. 1960;23:56-62. https://doi.org/10.1136/jnnp.23.1.56

23. Akdemir A, Dönbak Örsel S, Dağ I, Türkçapar HM, İşcan N, Özbay H. Hamilton Depresyon Derecelendirme Ölçeği (HDDÖ)'nin geçerliği-güvenirliği ve klinikte kullanımı. 3P Dergisi. 1996;4:251-9.

24. Hamilton $M$. The assessment of anxiety states by rating. British Journal of Medical Psychology. 1959;32:50-5. https://doi.org/10.1111/j.2044-8341.1959.tb00467.x

25. YazıCı MK, Demir B, Tanriverdi N. Hamilton Anksiyete Değerlendirme Ölçeği, değerlendiriciler arası güvenirlilik ve geçerlilik çalışması. Türk Psikiyatri Dergisi. 1998;9:114-7.

26. Wewers ME, Lowe NK. A critical review of visual analogue 
scales in the measurement of clinical phenomena. Research in nursing \& health. 1990;13:227-36. https://doi.org/10.1002/nur.4770130405

27. Straus MA. Measuring intrafamily conflict and violence: The Conflict Tactics Scales. Journal of Marriage and the Family. 1979;41:75-88. https://doi.org/10.2307/351733

28. Akyazi S, Tabo A, Guveli H, Illnem MC, Oflaz S. Domestic Violence Victims in Shelters: What Do We Know About Their Mental Health? Community Mental Health Journal. 2018;54:361. ttps://doi.org/10.1007/s10597-018-0240-1

29. McEwen BS. Protective and damaging effects of stress mediators. The New England Journal of Medicine. 1998;338:171-9.

https://doi.org/10.1056/NEJM199801153380307

30. Eberhard-Gran M, Schei B, Eskild A. Somatic symptoms and diseases are more common in women exposed to violence. Journal of General Internal Medicine. 2007;22(12):1668-73. https://doi.org/10.1007/s11606-007-0389-8

31. Leserman J, Drossman D A, Li Z, Toomey TC, Nachman G, Glogau L. Sexual and physical abuse history in gastroenterology practice: How types of abuse impact health status. Psychosomatic Medicine. 1996;58:4-15. https://doi.org/10.1097/00006842-199601000-00002

32. Kendall-Tackett K, Marshall R, Ness K. Chronic pain syndromes and violence against women. Women \& therapy. 2003;26(1-2): 45-56.

https://doi.org/10.1300/J015v26n01_03

33. Martínez-Lavín M. Disrregulación autonómica en la fibromial- gia: Implicaciones patogénicas y terapéuticas. XXXI Congreso Español de Reumatología. Las Palmas (España). 18-20 Mayo 2005.

34. Finestone HM, Stenn P, Davies F, Stalker C, Fry R, Koumanis J. Chronic pain and health care utilization in women with a history of childhood sexual abuse. Child Abuse \& Neglect 2000;24:547-56.

https://doi.org/10.1016/S0145-2134(00)00112-5

35. Walker EA, Keegan D, Gardner G, Sullivan M, Bernstein D, Katon WJ. Psychosocial factors in fibromyalgia compared with rheumatoid arthritis: II. Sexual, physical, and emotional abuse and neglect. Psychosomatic Medicine. 1997;59:572-7. https://doi.org/10.1097/00006842-199711000-00003

36. Häuser W, Hoffmann EM, Wolfe F, Worthing AB, Stahl N, Rothenberg $R$, et al. Self-reported childhood maltreatment, lifelong traumatic events and mental disorders in fibromyalgia syndrome: a comparison of US and German outpatients. Clinical and Experimental Rheumatology. 2015;33(1 0 88):8692.

37. Sallinen M, Kukkurainen ML. 'I've Been Walking on Eggshells All My Life': Fibromyalgia Patients' Narratives About Experienced Violence and Abuse. Musculoskeleteal Care. 2015;13(3):160-8. https://doi.org/10.1002/msc.1096

38. Aaron LA, Bradley LA, Alarcón GS, Triana-Alexander M, Alexander RW, Martín MY, et al. Perceived physical and emotional trauma as precipitating events in fibromyalgia. Arthritis \& Rheumatism. 1997:40:453-60. https://doi.org/10.1002/art.1780400311 